\title{
XXXII. On feeding cattle with green food; together with other ingenious and valuable observations in agriculture
}

\section{Mr. Edward Powys}

To cite this article: Mr. Edward Powys (1805) XXXII. On feeding cattle with green food; together with other ingenious and valuable observations in agriculture , Philosophical Magazine, 22:87, 212-218, DOI: $10.1080 / 14786440508562445$

To link to this article: http://dx.doi.org/10.1080/14786440508562445

曲 Published online: 18 May 2009.

Submit your article to this journal $\pi$

山 Article views: 2

Q View related articles $\asymp$ 


\section{$\left[\begin{array}{lll}212 & 3\end{array}\right.$}

XXXI1. On feeding Cattle with green Food; together with other ingenious and valuaille Observations in Agriculture. By Mr: Edward Powys*.

I concerve the principal object respecting agriculture in the present state of this country, is to procure the greatest possible supply of the necessaries of life within the kingdom itself, and one principal means of doing this is, to raise the greatest produce from a given quantity of land.

To effect this, every encouragement should be given by land-owners to the cultivation of grain and turnips; because I look upon the produce of an acre of grain to be, to the produce of an acre of grass, in the proportion of at least fifteen to two, in furnishing the necessarics of life. I suppose the grain made into bread, and the grass digested by a feeding beast, and changed into an increase of weight.

One great means of increasing the grow th of grain and turnips, I think, would be to encourage the farmer to make as much manure as possible. This would be effected by allowing him to sell all his wheat and rye straw, with the restriction of laying out the whole price in manure; and by gentlemen, who have land in their hands, trying the experiment of keeping their cattle and horses in the house upon green food great part of the summer.

For these last six years I have sold all the wheat straw I did not want for thatching and the beds of certain kinds of horses, and can assure you that the same farm has produced for some years back one-third more grain, and keeps double the live stock it did six years ago.

As a proof that what I say of keeping cattle in the housc in summer upon green food is not matter of theory only, but of practice, I shall mention my own experience.

For these last five years I have kept eight or ten waggon horses in the stable upon clover, cut and carried for them once a day; the small waste that they made was thrown into a low cratch (or receptacle, with staves on each side) for my pigs, which have generally been from 25 to 40. My horses and pigs, thus fed, have eaten, between the beginning of May and corn harvest, from $2 \frac{1}{2}$ to $3 \frac{1}{2}$ acres, according to the goodness of the clover. My horses have been, by this means, in much better condition than if turned into a.field; there has been a saving of at least eight or ten acres of clover for other stock; a great deal of the richest

\section{* From Ceneral View of the Agriculture of Shropshire.}


manure has, been made (mich more, and richer, than in the same time in winter), and the additional daily expense has been, one man less than half his time, in cutting, raking, and carrying with a-horse and cart, one load each day.

Experiment.

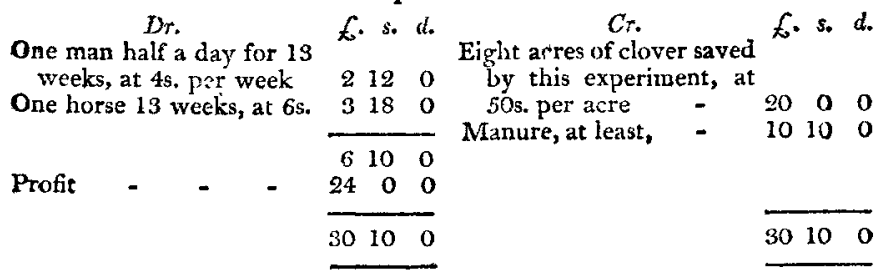

The first year I tried the experiment the manure made was estimated by a good farmer at 201 . ; but I wish to make allowance for the value of the straw, and the manure that would have been made by the horses standing in the stable the usual hours in summer.

I must endeavour to remove an objection that may perhaps be made to this experiment, by observing, that I cannot think land injured any more by the green food being cut by the scythe, than by cattle or horses; and as to the dung that is dropped in summer, it breeds flies, and does more harm than good. I have ever thought land exhausted infinitely more by its produce being suffered to ripen and seed, than by its being cut in a green state. The advantage I had derived from this expeximent, induced me last summer to try whether cattle might not be treated in the same way.

I began with putting into stalls 19 ; I afterwards increased my stock fed in this manner to 50, consisting of horses, feeding cattle, milking cows and colts, besides a large quantity of pigs.

The horses, as usual, answered well.

The feeding cattle came on much faster than I ever saw them in summer. The milking cows fed very much, and milked very well. The colts did well, and lived chicfly upon the refuse of the cattle. The pigs, as usual, ate the refuse of the horses.

The quantity of land run over with the scythe for this purpose was :

Fourteen acres of trefoil, very moderate, on account of the clover root having died in winter.

Two acres of vetches, very moderate, on account of the severe winter.

Five acres of very good grass. 
The cattle were turned out late at night for about six or seven hours.

The trefoil caused some trouble, on account of the cattle sometimes swelling, but brought them on very well, though they throve best upon the winter vetch or tares, and upon the grass. The daily expense was one old man of more than 70 , to feed and clean them, another young man to cut, rake, and carry the food with a single horse cart.

If this stock had been turned out I should suppose they would have run over at least 60 acres, if the crop had been good, and much more, if the indifferent trefoil is considered.

Experiment.

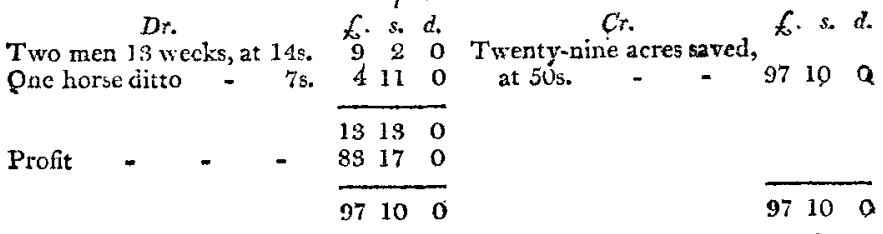

Any person that intends to practise this methor should begin to cut his green food so early in spring that he may be able again to mow the same ground from hay to corn harvest.

I have before observed, that I never saw cattle in summer come on so fast. I speak this, not only from my own observation, but from that also of several farmers and butchers, who came through curiosity or business frequently to visit them. The most feeding green food is winter vetches; and the most advantageous mode of cultivating them, I think, is to plough up a clean stubble (that is intended for turnips), manure it, and sow it with retches soon after corn harvest. When the vetches are all eut in May and June, or rather in the latter month, the field may be ploughed and sown with turnips for a winter crop.

From com harvest till September 22 , my cattle nere all out in the fields at grass. I then took up thirty into stalls, and fed them with turnips which had been sown early in May, and which had arrived at a very good size. My first field of turnips has been carried off, plonghed and sown with wheat, which has been above the ground some time, and looks very promising.

I have practised this scheme of sowing turnips in May, carrying them off before the beginning or end of the following November, and then sowing the piece with wheat, for these last three years. And I have found this wheat much 
much more productive than any sown after any other crop or fallow. I am speaking of dry suwn land.

One year I got up all the turnips of a field, topped and butted them (throwing the tops and butts in heaps by themselves), carried the tops immediately as they were cut to a bare stubble for my catile and sheep, and laid the butts up in large heaps cither under cover or in my stack-yard, with straw over them. Where there wis no straw in layers between them, they kept for two or thrce months; some that hal layers of straw every foot or half yard perpendicular, soon began to decay near the straw, which was made to heat by the moisture from the turnips.

Erom these experiments upon turnips, and from observing that dry laud of my own, though it produced crops of grain or turmips for many years together, with the change of clover (mown twice in the same year) only once in five years, did not lose any of its power, I have conceived that much more grain might be produced upon well cultuvated farms. Wet land that is wall cultivated might bear, in regular succession, crops of turnips, wheat, aud barley or oats. Dry sound land may also bear the same succession when an early crop of turnips is wanted; and when turnips are wanted to stand the winter, a succession of turnips, barley, and wheat.

I think it is much more advantageous to carry all the turnips to cattle in stalls (excopt a very for left for sheep) than to eat them on the land, because they furnish much more food and manure. I am aware that many gentlemen of landed property will object to this constant tillage: in answer to which I shall only observe, that it has been my opinion and practice never to have any grass land that is not worth $40 \mathrm{~s}$. an acre; never to plough my grass land, but to till the rest constantly, with the intermission now and then of turnips and clover, the latter only for one year.

The farm I have above alluded to is about 240 acres, of which $I$ have in grass land about 90 acres; in tillage for grain and turnips about 120 acres. The rest is generally clover, unless I have a single fallow for wheat upon a ficld of wet land.

I repeat it once more, that the interests of the public, of the landlord, and tenant, (for I know of no distinction when many years are taken into consideration) are united in the greatest produce of the necessaries of life; and that if arable land is kcpt clean and full of manure, it reccives no injury from producing the greateit quantity of grain. The in- 
creased produce of land benefits the public in too obrious a manner to enlarge upon. It benefits the landlord, by lias being able, at the expiration of certain fair intervals, to raise the rent of his farm; and the tenant or occupier, by getting more profit from a given quantity of land, and,with nearly a given capital.

I have recommended turnips once in three years, because 1 think land requires eleaning once in that time, and because it is thus effected without losing the benefit of a crop in any year.

Much has been Jately said about the superior advantage of cattle over horses in farmers' teams. I think some horses must be kept for the farmer to take his grain to market, and to carry his coal and lime. If he is so near a large town that he can draw at least two load of dung in a day, he will also want them for that purpose. Other team-work may very well be done by cattle. But I think cows are much more useful and beneficial than oxen, and that it would be an advantage to the kingdom if few or no oxen were reared. The use's of cattle are to work, milk, and feed. I have seen barien cows work as well as oxen; they require less keep, and walk faster. Oxen are of no use to the dairy, and they will not feed so fast as cows.

When first I commenced farmer I followed the example of my predecessor, in feeding chiefly oxen; but I soon found that cows fed much faster and on less meat, and for some years past have carefully avoided having any oxen in my stalls.

\section{Meadows.}

It should be considered as a great object of every landlord, or his steward, to procure watered or flooded meadows.

The best means of doing this is, to place the farm-yard on such an eminence of the farm that a stream can be procured to run through it, and afterwards over the greatest "iuantity of meadow land.

Common meadows ought: to be well manured once in three years, and will then produce one ton and a half of hay per acre, and a pasture from the middle of September to Christmas.

Good watercd meadows will bẹar to be grazed from the beginning or middle of August till May following, and will, between that time and hay harvest, produce one-fourth of hay more than the other. 
The difference of the profit of watered meadows over common, I think, is annually as underneath :

One-third of 51 . (the expense of manuring an

\begin{tabular}{llrrr} 
acre of land) & - & 1 & 13 & 4 \\
One-half ton of hay additional & - & 1 & 5 & 0 \\
Difference of the value of grazing & - & 0 & 11 & 8 \\
\hline & $E .3$ & 10 & 0
\end{tabular}

But besides the produce and profit, there are two other very great advantages in watered meadows. The one, saving manure for arable land, the other keeping the pastures free from stock the beginning of spring.

I have hitherto only mentioned a stream that runs through a farm-yard, but $I$ bave frequently observed very great advantages cierived from nothing but clear spring water being turned over grass land.

If a farmer has a greater command of water than he wants for his meadows and pasture land, he may occasionally till some of them for two or three years, and they will produce great crops without manure. I saw this practised with great success, this last summer, by the late Mr. Bakewell, of Dishley, Leicestershire.

\section{Size of Farms.}

Much has been lately said upon the size of farms, from the high price of grain being supposed to arise from the opulence of the farmer, and his being able to keep back his grain from the market. I might combat this assertion by the well known fact, that at the harvest of 1794 there was not a fortnight's consumption of wheat in the kingdom, and yet the price was moderate. I might also add, that there never was so much wheat brought to market before Christmas as has been for these last two years, and that it has only been when wheat was plentiful that any of the stock remained in stacks at harvest; but I think the high price is known by sensible thinking people to arise from other causes. I shall therefore proceed to observe, that farms of from 200l. to 800l. per annum, and upwards, are much more beneficial to the public, the landlord, and tenant, than farms of from 50l. to iool. per annum. The public are benefited by fewer people and horses being kept upon one farm of 30ol. per annum, than upon six of 50l. pach to do the same work, and therefore by a greater produce being left, after the supply of the families, for the consumption of the kingdom at large. 
The landlord is benefited by having fewer buildings to erect and repair, and by having more opulent tenants. The benefit of a large farm to the occupier I need not enlarge upon. The misery of the small farmer, under 5ol. per annum, is extreme. He has not constant employment for himself and family (if at all large) upon his farm; he is in general above working day labour, is unable to exert himself and improve his small tract of land, and sits by the fire-side with his famiiy great part of the winter, lamenting that his farm and his capital are not larger, and brooding nothing but discontent and indolence.

But while I am making these observations upon the adrantage of large over small farms, let me notice the great benefit and comfort that the common workman, in any line, derives from sufficient grass land being attached to his dwelling to keep a cow in summer and winter. The landlord will also rcceive benefit, as well as self-satisfaction, from being the cause of the plenty that the produce of a cow makes in a large and poor family.

I can from experience assert, that the cottager can afford to give his landlord one-third, if not one-half, more for that small quantity of land than a farmer. The value of the cow is generally more than one year's rent, and the addition of a small cow-house is a trifing expense.

I cannot help recommending this the more strongly, because I know well, from experience, the astonishing comfort and advantage that a poor family receives from the produce of its cow, and that it is also for the interest as well as inward satisfaction of the landlord.

XXXIII. New Process for decomposing Sulphate of Barytes in order to prepare the Muriate of that Earth; with a Method of preparing the Muriate. By M. GoettLing**.

M Luriate of barytes is now so generally used, that every improvement in the mode of preparing it must be favourably received. M. Goettling's new method is as follows :

The decomposition of sulphate of barytes by means of charcoal requires a strong fire continued a long time, and never succeeds completely. This is owing, on the one hand, to the strongly oxygenated quality of the acidifying principle in the sulphuric aoid, so that in its transiation to

* From Taschen-luch fur Scheidkunstler. 